\title{
Improving Capability of Principal Preparing School Development Plan (SDP) Through Managerial Supervision with Monitoring and Evaluation Methods in Sub Rayon MTsN 3 Kota Medan
}

\author{
Rahmatul Ummah \\ Educational Administration Postgraduate \\ Program \\ Universitas Negeri Medan \\ Medan, Indonesia \\ r_ummah@yahoo.com
}

\author{
Zainuddin \\ The Lecturer of Universitas Negeri \\ Medan \\ Medan, Indonesia
}

\author{
Darwin \\ The Lecturer of Universitas Negeri \\ Medan \\ Medan, Indonesia
}

\begin{abstract}
The purpose of this school action research was to determine the capacity building of principal in the preparation of the School Development Plan (SDP) through managerial supervision of the monitoring and evaluation methods in Sub Rayon MTsN 3 Kota Medan. The subjects of this research are five principals of Sub Rayon MTsN 3 Kota Medan namely MTs IslamiyahSunggal, MTs Al Azhar, MTs Hasanuddin, MTs Muhammadiyah 01 and MTs Cendekia. The subject was determinedpurposively. The research instrument to improve the ability of principals in the School Development Plan (SDV) preparation using 14 guidelines list observation.Results of the study are the assessment of the ability of the principal in preparing the School Development Plan (SDP). In pre cycle, the ability of the principal in developing the School Development Plan (SDP) was still low at 45.00 , after the action on the first cycle occurred increased to 67.50 , but do not meet the criteria of $80 \%$ is expected, after efforts to improve managerial supervision and monitoring methods evaluation in the second cycle, then an increase became 86.07 in the good category. In the second cycle of all respondents (principals) have met the success criteria that have been set that is $>\mathbf{8 0} \%$. Based on the results of the action research in first cycleI and second cycle, can be concluded that the ability of the principal in preparing the School Development Plan (SDP) can be improved through managerial supervision with monitoring and evaluation methods at the Sub Rayon MTsN 3 Kota Medan.
\end{abstract}

Keywords:The ability of the principal, Supervision, Monitoring and Evaluation

\section{INTRODUCTION}

At present, schools must deal with new provisions, especially related to Government Regulation Number 19 of 2005 concerning National Education Standards (NES) Educational standards are a minimal concept of the education system in various laws of the Republic of Indonesia, which consists of eight standards, namely: standards of content, processes, competencies, educators and education personnel, facilities and infrastructure, management, financing and assessment. Thus each school is required to compile, implement, and evaluate the School Development Plan (SDP) in order to achieve these standards and also improve its quality to a higher standard. In this case, the principal becomes the main and main key of education in Indonesia. The principal has an important role in coordinating, mobilizing, and optimizing all resources, and the relevance and competitiveness of education. As a consequence, principals must have managerial qualifications and competencies as stated in Minister of National Education Regulation No. 13 of 2007 concerning Principal Standards, which among others relate to the ability of principals to develop School Development Plans (SDP) for various levels of planning [5]. Planning that is prepared must be a comprehensive plan to optimize the use of all available and possible resources to achieve the desired goals in the future [3]. But in reality in the field, there were a number of facts that there were still many principals who were not yet fully able to develop school development plans (SDP) properly. This is caused by several things, including: principals are still having difficulty in preparing the SDP, most principals do not form a working group whose job is to develop and formulate the goals and results to be achieved by the school, the low managerial competence of principals and lack of roles and functions school supervisors in providing guidance and guidance for school principals related to the administration and School Development Plan (SDP). Seeing the phenomena that occur, it is important to conduct research directly to the field related to the problem of the ability of the principal in preparing the School Development Plan (SDP), so that after initial observation to get the latest information and the results are not much different from the problems that have been found before.

From a brief interview conducted by several Medan City Ministry of Religion supervisors along with a questionnaire that had been filled by 24 madrasah heads in Sub Rayon MTsN 3 Kota Medan, there were still the following: (1) $60 \%$ or around 14 schools did not have a document School 
Development Plan(SDP) and only $40 \%$ or around 10 schools have, but the is incomplete and not reality and operational; (2) $50 \%$ or approximately 12 principals do not understand and have never attended training on how to prepare a School Development Plan (SDP) with the correct procedures and methods; (3) $40 \%$ or around 10 schools have never formed a School Quality Development Team. This is certainly an obstacle for school principals, especially in the preparation of the School Development Plan (SDP), it will be difficult for a school principal to work alone without assistance from related parties; (4) $50 \%$ or approximately 12 principals have not received guidance and services from school supervisors related to management, administration and School Development Plans (SDP).

Based on observations, the aspect that needs to be improved for the principal is the ability to develop a School Development Plan (SDP). This idea was reinforced by Mulyasa that there was a need for research on school actions regarding SDP preparation, including: (1) At present the development of science, technology and art takes place at any time, so that its development is fast. This is certainly very influential on the education system in schools, both in planning, process and educational outcomes. How schools are conditioned to be able to keep up with these developments and changes, it is clear that there needs to be school action research related to the preparation of the School Development Plan (SDP) that is in accordance with the preparation of science and technology and the needs of the community; (2) the rapid development of the population requires large education services, with a large cost or education budget. In addition, the right strategy is also needed so that education can be enjoyed by all citizens equally, both in quantity and quality. In this framework, it is also necessary to conduct school action research to develop SDP that is appropriate to the development of the population; (3) Quality human resources are basic capital as well as being the key to the success of national development if the quality of human resources can be improved and utilized. That way the Indonesian economy will grow and develop so that it can provide relatively high national income. This is a challenge for schools, how to produce qualified graduates, not only capable and skilled in doing work, but also having honest and trustworthy quality, having high innovation and creativity and having a vision that is far ahead; (4) the rapid development of information technology in the 21 st century has led to various thoughts, not only in the business and economic world, but also in the world of education. To face the challenges of the future as a result of progress and development, school action research activities are needed to develop SDP [4].

Realizing this, every school principal is required to be able to prepare a School Development Plan (SDP) in a directed, planned and sustainable manner so that he can improve the quality of education he leads. In this framework, before conducting managerial supervision, it is necessary to choose a method so that the implementation of managerial supervision can achieve the stated goals. Monitoring and evaluation of the primary method that must be mastered by the school superintendent in order to perform its functions and its role in order to improve the quality of education in schools mainly target schools. Aspects that are observed in this monitoring and evaluation are generally all things that are developed and implemented in the School Development Plan (SDP). Monitoring and evaluation activities to explain the real situation related to aspects of the School Development Plan (SDP) that can be generated recommendations, feedback or fixes in the future in order to improve the quality of schools.

\section{METHODOLOGY}

The study was conducted from February 2018 to April 2018. The school principals who were the subject of this study amounted to five people, namely the head of MTs IslamiyahSunggal, head of MTs Al Azhar, head of MTs Hasanuddin, head of MTs Muhammadiyah 01 and hHead of MTsCendekia. Determination of the subject in this study is purposive, namely the technique of determining the sample with certain considerations.

This study used school action research. School Action Research aims to find solutions to real problems that occur in schools, while seeking scientific answers to how these problems can be solved through a corrective action. Various principles and indicators of School Development Plans (SDP) can be applied effectively if the implementation is carried out through school action research. The study was carried out with a cycle strategy that departed from the identification of problems faced by the principal, the preparation of action plans, implementation of actions, action observations, and reflections. Sequential activities ranging from action plans to reflections are called one research cycle. Each cycle consists of four stages, namely (1) action planning, (2) action implementation, (3) observation and interpretation, (4) analysis and reflection. These stages keep repeating until the problem is resolved or the success indicator has been reached.

Data collection instruments used were (1) observation sheets to assess the ability of principals to develop School Development Plans (SDP); (2) observation sheets to observe the actions of supervisors in carrying out managerial supervision of monitoring and evaluation methods; (3) documentation study (photo) as supporting data in managerial supervision activities monitoring and evaluation methods. Data analysis used in this study is the analysis of the assessment of the ability of principals in developing School Development Plans (SDP). The data that has been collected is analyzed by comparing the data before the action and the data after the action, namely the results of observations of the principal in preparing the School Development Plan (SDP) and then measuring the increase with the formula [1] as follows:

\section{Value $=\frac{\text { Total Earnings Score }}{\text { Total Skor Maximum }} x 100$}

With the following score ranges and categories [2]: 
TABLE 1Rating and value of Principals Preparing School Development Plans

\begin{tabular}{|c|c|}
\hline Rating & Value \\
\hline Very Good & $90-100$ \\
\hline Good & $80-89$ \\
\hline Enough & $70-79$ \\
\hline Less & $60-69$ \\
\hline Very Less & $<60$ \\
\hline
\end{tabular}

In determining the indicator of success of the principal in developing the School Development Plan (SDP) is determined by the school supervisor. This action research is said to be successful if all school principals who are the subject of research reach a value of $>80$.

\section{RESULTS AND DISCUSSION}

\section{Pre-Cycle Description}

The implementation of the pre-cycle activities provides an overview of the conditions and initial capability conditions of the five principals in developing the School Development Plan. Based on the results of the observations obtained, it was shown that the ability of the principal in preparing the School Development Plan (SDP) was still low and included in the very low category with a value of 45.00 . The pre-cycle phase shows that the ability of the principal to develop a School Development Plan (SDP) in classification is lacking, so that supervisors and researchers take the initiative to improve the ability of principals to improve and fulfill the indicator components that remain obstacles for principals in developing School Development Plans (SDP).

\section{Description of Cycle I}

In the first cycle the action research was carried out consisting of four stages: action planning, action implementation, observation, and reflection, where this activity was the first action after knowing the initial condition of the principal's ability to develop a School Development Plan. The results of the overall score analysis showed that the ability of the principal in developing the School Development Plan (SDP) in the Sub Rayon MTsN 3 Kota Medan was still low and included in the unfavorable category with a score of 67.50 . Based on the description above, shows that the ability of the principal in preparing the School Development Plan (SDP) in the first cycle is less optimal and poor classification, so that the supervisor and researcher take the initiative to improve the ability of the principal to improve and fulfill the indicator components that are still become an obstacle for school principals in preparing School Development Plans (SDP) so that it needs to be done in cycle II.

\section{Description of Cycle II}

After knowing the results of the evaluation of the first action, the second action is carried out with reference to the scenario that has been prepared. The results of the implementation of cycle II on the ability of principals to develop School Development Plans (SDP) through managerial supervision of monitoring and evaluation methods by school supervisors showed that the ability of principals in the preparation of School Development Plans (SDP) in the Sub Rayon MTsN 3 Kota Medan has increased and included in the good category with a score of 86.07 so that the success indicator has been reached, and the research cycle is complete.

The results of the acquisition value from pre-cycle, cycle I and cycle II data can be seen in the following table:

TABLE 2. Pre-cycle Data Value, Cycle I and Cycle II

\begin{tabular}{|c|l|c|c|c|}
\hline \multirow{2}{*}{ No } & \multirow{2}{*}{ School Name } & \multicolumn{3}{|c|}{ Value } \\
\cline { 3 - 5 } & & Pre-cycle & Cycle I & Cycle II \\
\hline \multirow{2}{*}{1} & MTs Islamiyah Sunggal & 73.21 & 55.35 & 91.07 \\
\hline 2 & MTs Al Azhar & 69.64 & 44.64 & 89.28 \\
\hline 3 & MTs Hasanuddin & 66.07 & 41.07 & 83.92 \\
\hline 5 & MTs Muhammadiyah 01 & 67.85 & 42.58 & 85.71 \\
\hline 6 & MTs Cendekia & 60.71 & 41.07 & 80.35 \\
\hline
\end{tabular}

In table 1 above show the average score of the overall score from pre-cycle, cycle I and cycle II. The average score in the pre-cycle is 45.00 with very less categories. Cycle I with a score of 67.50 with less categoryand cycle II with a score of 86.07 with a good category. In cycle II all principals have met the criteria for success indicators, namely> $80 \%$. Overall data starting from pre-cycle, cycle I and cycle II are illustrated in the following diagram: 


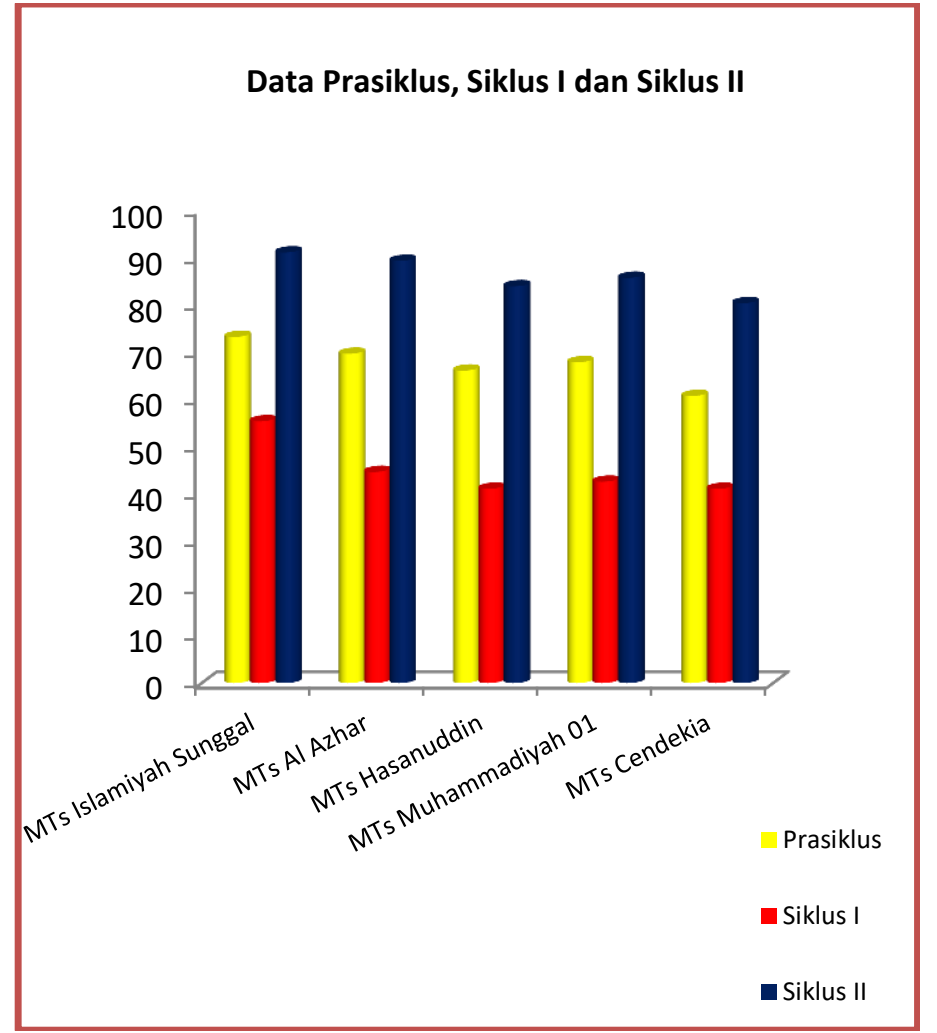

Diagram 1. Pre-Cycle Data Value, Cycle I and Cycle II

\section{CONCLUSION}

Based on the results of research conducted in this study, the following conclusions were obtained:

1. In the pre-cycle stage, there is an illustration that the ability of the principal in preparing the School Development Plan (SDP) in the Sub Rayon MTSN 3 Kota Medan is still low and is included in the very less category with a value of 45.00 .

2. In the first cycle the results of the overall score analysis showed that the ability of the principal in preparing the School Development Plan (SDP) in the Sub Rayon MTSN 3 Kota Medan was still low and included in the less category with a score of 67.50.

3. In cycle II the completeness criteria in preparing School Development Plans (SDP) have been achieved with the mean scores of the ability of principals, namely 86.07 in the good category.

4. The results of action research in cycle I and cycle II can be concluded that the ability of the principal in preparing the School Development Plan (SDP) can be improved through managerial supervision of monitoring and evaluation methods in the Sub Rayon MTSN 3 Kota Medan.

\section{REFERENCES}

[1] Endrayanto, Herman Yosep dan Yustiana Wahyu Harumurti. 2014. Penilaian Belajar Siswa di Sekolah. Yogyakarta: Kanisius.

[2] Kemdikbud.2016. Bahan Pembelajaran Diklat Peningkatan Kompetensi Manajerial, Penyusunan Program dan Monitoring \&Evaluasi. Jakarta: Lembaga Pengembangan dan Pemberdayaan Kepala Sekolah (LPPKS) Indonesia.

[3] Muhaimin, H. 2012. Manajemen Pendidikan: Aplikasi dalam Penyusunan Rencana Pengembangan Sekolah/Madrasah. Jakarta: Kecana Prenada Media Grup.

[4] Mulyasa, H.E. 2009. Penelitian Tindakan Sekolah. Bandung: PT Remaja Rosdakarya.

[5] Permendiknas Nomor 13 Tahun 2007 tentang Standar Kepala Sekolah/Madrasah.

[6] Peraturan Pemerintah Nomor 19 Tahun 2005 tentang tentang Standar Nasional Pendidikan (SNP). 